\title{
October 2019 SAPHIRE 8 Software Quality Assurance; Maintenance and General Support Status Report
}

James K Knudsen, S. Ted Wood

October 2019

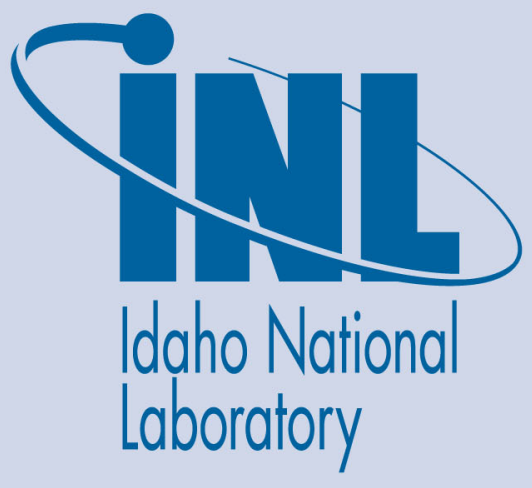

The INL is a U.S. Department of Energy National Laboratory operated by Battelle Energy Alliance 


\title{
October 2019 SAPHIRE 8 Software Quality Assurance; Maintenance and General Support Status Report
}

\author{
James K Knudsen, S. Ted Wood
}

October 2019

Idaho National Laboratory Idaho Falls, Idaho 83415

http://www.inl.gov

Prepared for the U.S. Department of Energy Office of Nuclear Energy Under DOE Idaho Operations Office Contract DE-AC07-05ID14517 


\section{October 2019 SAPHIRE 8 Software Quality Assurance; Maintenance and General Support Status Report}

\section{Current activities and progress related to the SAPHIRE 8 Quality Assurance Program; Maintenance and General Support}




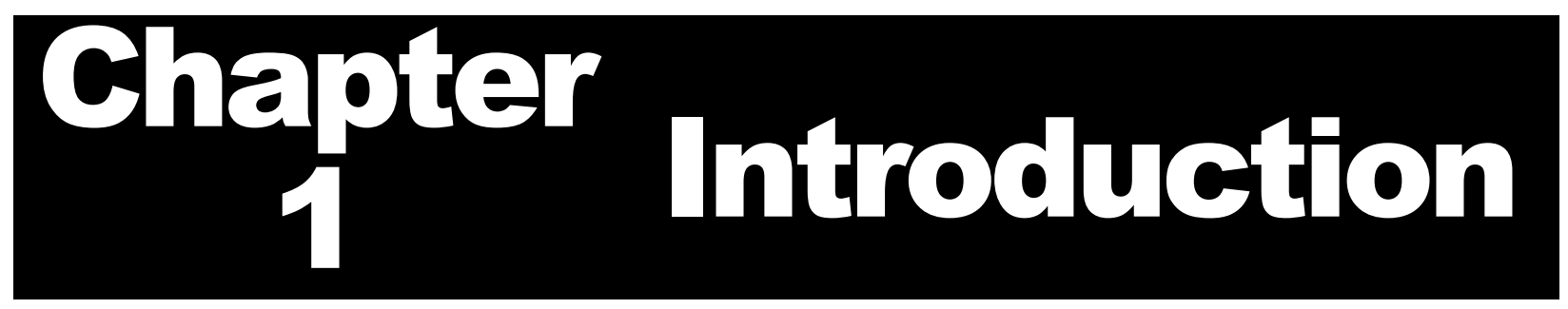

\section{Background}

The Software Quality Assurance (SQA) engineer position was created in fiscal year (FY) 2011 to better maintain and improve the quality of the System Analysis Program for Hands-on Integrated Reliability Evaluations (SAPHIRE) 8 development program. The SQA program originated under Nuclear Regulatory Commission (NRC) Job Code Number (JCN) V6059 which had a period of performance from August 1, 2010, through July 31, 2015. The SQA program then transitioned to NRC Interagency Agreement (IAA) NRC-HQ-60-15-D-0010 which had a period of performance from August 1, 2015, through July 31, 2017. The SQA program is now covered under NRC IAA NRC-HQ-60-17-T-0006 SAPHIRE 8 Code Maintenance and Quality Assurance (QA) Activities with a period of performance from July 1, 2017, through June 30, 2022.

This letter report highlights the SQA tasks that concentrated on the continued operation of the implemented framework of the SQA program along with the maintenance and general support activities of SAPHIRE for the duration of June 2019 - October 2019.

This report is divided into two distinct parts: 1) SQA activities and 2) Maintenance and General Support activities. This letter report documents the accomplishments and recommendations for each of the main tasks (SQA activities and Maintenance and General Support).

The SQA activities is divided into four subtasks and are listed below as set forth in NRC-HQ-60-17-T0006:

- Reviews, Tests, and Code Walkthroughs.

- Oversight on SAPHIRE Quality Assurance (QA) Activities.

- Support Nuclear Regulatory Commission (NRC) Presentations and Meetings.

- SAPHIRE Improvements to support new Standardized Plant Analysis Risk (SPAR) Model features being developed including those for use in Level 2 and Level 3 PRA analyses.

The Maintenance and General Support activities is broken into two subtasks and are listed below as set forth in NRC-HQ-60-17-T-0006:

- Bug Fixes and Maintenance Activities.

- General Support Activities 


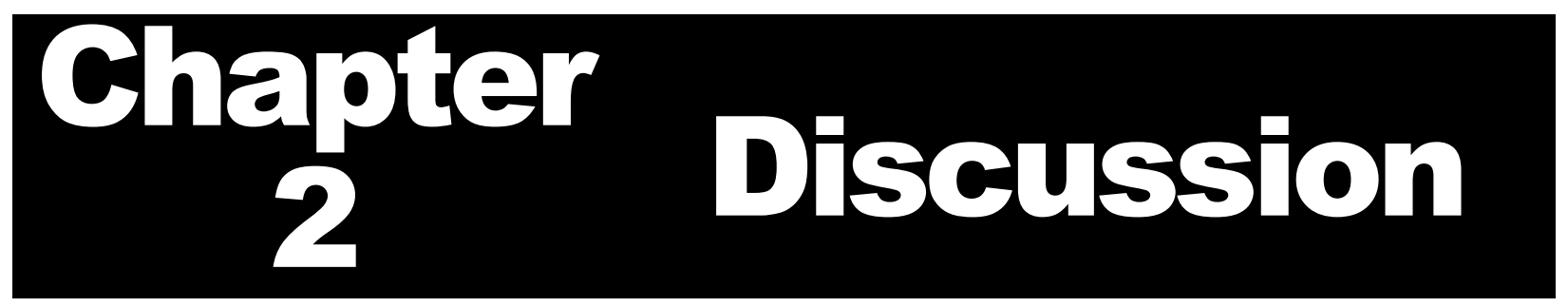

\section{Subtask 1.1 Reviews, Tests, and Code Walkthroughs}

\section{Description}

The activities of the SQA member in this subtask include, but are not limited to:

- Perform or assist in peer reviews or code walkthroughs.

- Review test results and perform tests.

- Tests performed may be static, functional, or acceptance testing as determined by the SQA member.

- Determine if commercial software is available to assist in performing these tests, and if so shall request that the NRC Contracting Officer's Representative (COR) approve its purchase.

- Perform Preliminary Design Review (PDR) and Critical Design Review (CDR) activities.

- Write formal documentation on SAPHIRE PDRs and CDRs describing what these reviews are and how and when these reviews will be done.

- Coordinate SAPHIRE PDR and CDR activities.

○ Document these reviews, tests and code walkthroughs.

\section{Accomplishments}

The SAPHIRE website was monitored between June 2019 and October 2019 to identify important software fixes and improvements. During the website monitoring, the latest issues identified in Version 8.2.0 were discussed with the programming staff. The issues reproduceable were fixed and will be in the next release, Version 8.2.1. Work still needs to be performed on fixing the other identified issues and these fixes will also be included in the next release, Version 8.2.1.

During the period between June 2019 to October 2019, work was performed on bug tracking and trending as part of the software metrics. The software metrics based on bug tracking and trending helps improve the quality of SAPHIRE. This tracking process is used to organize and prioritize maintenance activities for future SAPHIRE releases to ensure important code errors were addressed and fixed. The code errors are categorized in one of three different levels (i.e., high, medium, or low) along with the type of issue (e.g., calculation bug or user interface bug). Information about the software metrics is discussed and plots are provided in the report "October 2019 Software Quality Assurance Oversight Status Report," which is included in this transmittal.

The SQA member reviewed modules for standards compliance. There were no formal reports created 
for these reviews.

\section{Recommendations}

If new enhancements are requested for SAPHIRE, the SQA member should be present for design reviews and help in the development of the design documentation. The SQA member should review the preliminary design reviews (PDRs) and critical design reviews (CDRs) when each phase of the design feature moves on to the next phase: PDR to final design, CDR to implementation.

Peer-reviews and code walkthroughs will continue to be performed prior to the official release of new versions of SAPHIRE. The peer-review and manual code walkthroughs are required to avoid missing any potential code errors introduced during programming operations. All pre-releases need to be reviewed by the SQA member, NRC personnel and INL personnel working on the SPAR model project. The SQA member has a formal checklist that is used to verify multiple manual operations to try and identify any potential errors prior to release of SAPHIRE. The checklist is a living document and new tests will be added on an as needed basis.

The bug tracking system on the SAPHIRE website is an important tool to help improve the software quality of SAPHIRE. This bug tracking system allows registered SAPHIRE users to communicate issues (bugs or desired improvements) they encounter when using the software. The system allows users to examine issues that were previously identified and how they were resolved. When issues are identified by users or INL staff, they need to be documented in the bug tracking system. Training SAPHIRE users and INL staff to document and review any issues is vital to the improvement to SAPHIRE. Improvements of SAPHIRE, a mature software product, primarily comes from its use and notation of its weaknesses. The bug tracking system also keeps a complete list of issues that have been identified and fixed along with future possible enhancements.

\section{Subtask 1.2 Provide Oversight on SAPHIRE 8 QA Activities}

\section{Description}

The SQA member shall provide oversight on SQA activities, including but not limited to the following:

- Maintaining and implementing SAPHIRE 8 Software Quality Assurance Plan consistent with the requirements of NUREG/BR-0167, "Software Quality Assurance Program and Guidelines."

- Ensuring the revision control system (RCS) is up to date and contains all important documentation and files.

- Writing a document on what the RCS is and list its contents.

- Maintaining and updating software developer tools and documents that may include but are not limited to the following:

- Data dictionary

- Software metrics to improve software quality

- Coding guidelines

- Developer procedures and standards 
- Reviewing and updating SAPHIRE QA documentation, accounting for relations between documentation. Include the following documentation (as well as others as applicable):

- Acceptance Test Plan

- Configuration Management Plan

- QA Plan

- Project Plan

- Requirements Traceability Matrix (RTM)

- RTM software package reports

- System Test Plan

- Change Design and Testing Procedures

- Software Verification and Validation (SV\&V) Plan

- Significance Determination Process (SDP) Interface training manual

- SAPHIRE 8, "New Features and Capabilities Overview"

- Supporting an annual NRC audit of the SQA implementation against requirements of NUREG/BR0167, "Software Quality Assurance Program and Guidelines."

- Implementing SQA improvements at the request of the NRC Alternate (ALT) Contracting Officer's Representative (COR) and approval by the NRC COR.

\section{Accomplishments}

The SQA member reviewed the different quality assurance reports to make sure they are current and then placed them on the RCS for storage and record keeping. The SQA member reviewed the RCS to ensure it is up to date with the latest versions of the quality assurance documents.

Minor updates have been performed on the QA documents since June 2019. The "SAPHIRE Version 8 Software Verification and Validation Plan Volume 2" was updated to incorporate the work performed on updating the RTM. This document was placed back in the RCS.

The RTM has been updated to make sure the new features have been added and cross-checked with required tests. The inclusion of new manual tests has been added based on the latest versions of SAPHIRE. No new additional automated tests were added, but additional automated tests may be added to verify the newly added features meet the requirements. This was completed prior to the end of the FY-19. The cross referencing ensures all new and old features are properly being tested and documented.

\section{Recommendations}

The SQA member will continue to monitor and maintain the RCS and the QA documents that are located on the RCS. The SQA will also continue to monitor the code files in the RCS for meeting standards and RCS usage. The SQA will make sure the new tests become part of the automatic testing suite and verify the results to make sure they are correct prior to checking against the future versions of SAHPIRE.

The current automatic tests need to include more of the latest versions of the SPAR models since the complexity of the models have increased along with new features in SAPHIRE. Currently, the new features are tested with the appropriate model. However, the tests will eventually migrate towards using the latest versions of the SPAR models along with the standard set of models. This process will start during FY-20 provided resources remain available. 


\section{Subtask 1.3 Support NRC Presentations and Meetings}

\section{Description}

Provide support for the NRC presentations and meetings at the request of the NRC ALT COR and approval by the NRC COR.

\section{Accomplishments}

Teleconferences were held each month to discuss work that has been performed on both the SAPHIRE software and the SPAR models. These teleconferences allowed for discussions on SPAR model use and enhancements along with potential features to be added to SAPHIRE. These calls are important to make sure the NRC customers of the SPAR models and SAPHIRE are fully aware of any updates to the SPAR models and SAPHIRE.

\section{Recommendations}

The SQA will continue to maintain all reports and other important information in an accurate and readily available format that can be provided to the NRC COR and NRC ALT COR. The SQA will also ensure the Idaho National Laboratory (INL) Project Manager (PM) and the development team are available to transmit this information or provide additional comments to the NRC COR or NRC ALT COR when requested.

The INL PM will continue to provide support to the monthly SAPHIRE/SPAR model teleconferences and quarterly webinars. These teleconferences and webinars are an important avenue to discuss SPAR model updates, SAPHIRE enhancements along with information to help inform the NRC SPAR model users.

The monthly meetings and webinars are very important to all SAPHIRE and SPAR users along with the development team to disseminate work performed and work to be performed in each arena. This information will help all parties understand what to expect when using SAPHIRE and the SPAR model along with future impacts.

\section{Subtask 1.4 SAPHIRE Improvements to Support New SPAR Model Features Being Developed Including Those for Use in Level 2 and Level 3 PRA Analyses}

\section{Description}

Monthly reviews of SAPHIRE improvements with the SPAR model development team.

Shakedown testing of pre-release improved versions by INL expert users to test features of the program that cannot be tested in the automated test suite.

Review of design specifications and SQA maintenance and documentation of associated design reviews. 


\section{Accomplishments}

The SPAR model team and SAPHIRE development team were in continuous discussions on issues identified during the SPAR model development along with any potential needs. If software issues were identified, they were added to the SAPHIRE website which tracks the identified issues. The SAPHIRE programing team then addressed the issues and documented them upon completion. The SAPHIRE team informs the SPAR modelers of the fix for verification. The fixed issues will then be part of the next released version of SAPHIRE and will be documented in the official release documentation.

If new features were requested, they were documented on the SAPHIRE website and discussed with the SAPHIRE project team. The SAPHIRE project team then discussed the enhancements with the NRC COR and Alternate COR to prioritize the new features prior to implementation into SAPHIRE. Once agreement has been established, the development of the PDR and CDR is implemented to track the new features.

\section{Recommendations}

The review meetings between the SPAR model team and SAPHIRE program team will continue to ensure SAPHIRE meets the needs of the SPAR modelers. The discussions will help improve the software's capabilities and user interface. 


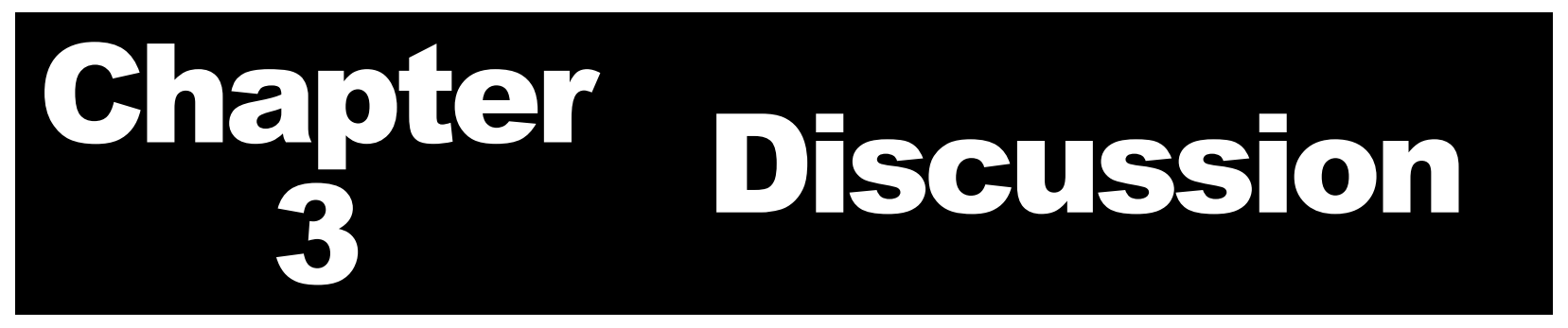

\section{Task 2. SAPHIRE Code Maintenance and General Support}

Task 2 covers maintenance of the code and provides support to NRC users as needed.

\section{Subtask 2.1 Bug Fixes and Maintenance Activities}

\section{Description}

The tasks include, but not limited to:

- Correcting programming errors identified.
○
Applicable SQA procedures shall be followed.
Programming errors that are corrected shall be

$\circ$

documented.

- Providing general code maintenance, such as maintaining code functionality (e.g., data input, printing, user-interface features, etc.).

- Review and improve legacy code, as appropriate, to make the code more maintainable.

- Maintain the SAPHIRE Risk Application Program Interface (API) as appropriate.

- Maintaining SAPHIRE help documentation.

\section{Accomplishments}

INL programmers continue to make improvements to the SAPHIRE software to meet the growing need of the user base. The primary users for testing and using the multiple applications of SAPHIRE are the Standardized Plant Analysis Risk (SPAR) model users and the Vogtle L3 project team. These groups provide the most feedback on issues identified with SAPHIRE to help make it more robust.

SAPHIRE Version 8.2.0 was officially released in August 2019. This new version required a schema change in order to extend the number of characters from 24 to 48 and to allow for Unicode characters.

Issues were identified in this new version of SAPHIRE from users, both SPAR model and external users and were documented on the SAPHIRE website. Some of the issues have been fixed and the remaining issues will be fixed and be part of the next released version 8.2.1.

\section{Recommendations}

As more features are added to SAPHIRE, it is important that the manual testing continues to expand in 
order to exercise these new features along with fixes. This manual testing needs to be as complete as possible to ensure software issues, if identified, are fixed prior to the new release. Part of the manual testing is to develop a complete model from start to finish and make sure all of the features and applications are included and tested (e.g., flag set development and convolution correction).

The automated testing suite needs to be updated to include more of the SPAR 8.50 models. The SAPHIRE models and the software are becoming more complex; therefore, the automated tests need be adjusted to ensure proper testing of the features. Prior to adding these models, the results will be verified via manual checks and against previous versions of SAPHIRE. This work is planned to start during FY-20 providing resources are available.

User documents need to be produced to detail any new features added to SAPHIRE. The user documents will provide additional information about the new features and how they are utilized. The new features have design documents that can be used as a starting point. Once the user documents have been developed and approved, they will be made available to all SAPHIRE Users.

\section{Subtask 2.2 General Support Activities}

\section{Description}

This subtask provides general support for NRC SAPHIRE users including, but not limited to:

- Providing incremental builds of SAPHIRE for NRC staff review.

- Make a new SAPHIRE build available to SAPHIRE users at the request of the NRC Alternate (ALT) Contracting Officer's Representative (COR) and approved by the NRC COR.

- Make incremental builds available on the SAPHIRE website at the request of the NRC ALT COR and approval by the NRC COR.

- Provide documentation describing each new build of SAPHIRE that is made available for general release on the SAPHIRE website. The documentation shall include the SAPHIRE revision number, a summary of the coding errors that have been resolved, and new software features.

- Performing the necessary activities related to configuration/maintenance of the SAPHIRE web site (https:\\saphire.inl.gov) where SAPHIRE software and SPAR models are stored for access by NRC users.

- Updating the SAPHIRE web site with the most current versions of the SAPHIRE software and SPAR models at the direction of the NRC ALT COR.

- Performing general project-management activities for this project.

- Maintain and update the SAPHIRE Users Group and Standardized Plant Analysis Risk (SPAR) model distribution websites at the direction of the NRC ALT COR.

- Maintain and update as needed the SAPHIRE Users Group website Security Plan.

- Maintain and Review User's Access to the SAPHIRE website.

\section{Accomplishments}

The SAPHIRE website was updated based on the direction of the NRC COR and the ALT COR to add and remove users from the website. Other SAPHIRE website maintenance was performed to make sure that it is operational for NRC users to download SAPHIRE and SPAR models. Also, the website was maintained 
to ensure the security plan is up to date and incorporated.

The Safety Portal was maintained and updated to ensure it remains operational to share large files between the NRC and INL. The one time download option developed and incorporated into SAPHIRE Version 8.2.0 using the Safety Portal was also maintained to make sure this feature functions properly. This feature allows SAPHIRE users to zip a model and share it with other SAPHIRE users who have Safety Portal accounts.

New SAPHIRE User Group members were added and a listing of these new members along with former SAPHIRE Users Group members as of October 21, 2019, is provided in Table 1. Table 2 provides account login details from June 19, 2019 to October 21, 2019.

\section{Recommendations}

The SAPHIRE website is the central location for the NRC and INL users to obtain the latest version of SAPHIRE and the SPAR models. The website provides a medium to report issues identified with the software or SPAR models. Therefore, maintaining the website to ensure its functionality and availability is important.

Continual monitoring and updating the SAPHIRE website to add and remove new users will continue to be performed. This process is important to the growth and use of SAPHIRE both internal to the NRC and external to the NRC. As more SAPHIRE users provide feedback on problems and desired features, SAPHIRE will continue to become more stable and powerful. Keeping track of the current SAPHIRE users is important for traceability. This monitoring will provide the NRC with information about the user group population both internal and external.

The Safety Portal is another important part of this project and therefore, continued work on maintaining it and updating the user interface and functionality is very important. These updates to the user interface ensure the continued ease to transfer files between INL/NRC, NRC/NRC, etc. The use of the Safety Portal in other areas can be advantageous. These uses are the development of the archive and share function as well as the one-time use download link. The archive and share function will allow SAPHIRE models to be archived and placed on the Safety Portal with only select users able to download the project. The one time use download link will help the NRC when transferring SPAR models to industry. The one-time link alleviates the need to develop compact discs containing the SPAR models. This link will allow INL or NRC to send the SPAR model to a non-INL or non-NRC person with a specific password for download and then the link will deactivate. 
Table 1. SAPHIRE Users Group Members (current and former).

\begin{tabular}{|c|c|c|c|c|c|}
\hline \# Users & $\begin{array}{l}\text { Account } \\
\text { Type }\end{array}$ & $\begin{array}{l}\text { Has } \\
\text { NDA }\end{array}$ & $\begin{array}{c}\text { Account } \\
\text { Disable Date }\end{array}$ & Description & $\begin{array}{c}\text { Self } \\
\text { Admin }\end{array}$ \\
\hline 4 & U.S. & Yes & Jan-21 & NuScale Power, Inc. & No \\
\hline 5 & U.S. & Yes & Oct-20 & Boeing - Huntsville & No \\
\hline 2 & U.S. & Yes & Oct-20 & Enercon & No \\
\hline 1 & U.S. & Yes & Aug-20 & Naval Undersea Warfare Center Division Newport & No \\
\hline 50 & INL & Yes & Aug-20 & The INL SAPHIRE User's Group & No \\
\hline 600 & NRC & No & Aug-20 & Nuclear Regulatory Commission & No \\
\hline 20 & U.S. & Yes & Jul-20 & INL Non-SPAR Account & Yes \\
\hline 5 & U.S. & Yes & Jul-20 & MARS2020-RIUWG & No \\
\hline 1 & U.S. & Yes & May-20 & Sterling Heights Associates LLC & No \\
\hline 5 & U.S. & Yes & May-20 & Missile Defense Agency & No \\
\hline 1 & U.S. & Yes & May-20 & Northrop Grumman - Missile Defense Agency & No \\
\hline 1 & Non-U.S. & Yes & Apr-20 & Nuclear Regulation Authority (NRA, Japan) & No \\
\hline 1 & U.S. & Yes & Mar-20 & FM Global & No \\
\hline 1 & U.S. & Yes & Jan-20 & MTechnology, Inc. & No \\
\hline 15 & U.S. & Yes & Jan-20 & ERIN Engineering and Research, Inc. (Jensen Hughes) & No \\
\hline 1 & U.S. & Yes & Nov-19 & Westinghouse Columbia Fuel Fabrication Facility & No \\
\hline 1 & Non-U.S. & Yes & Nov-19 & South African National Nuclear Regulator (NNR) & No \\
\hline 1 & U.S. & Yes & Oct-19 & NASA - Jet Propulsion Lab & No \\
\hline 1 & U.S. & Yes & Oct-19 & Meton Analysis, Inc. & No \\
\hline 2 & U.S. & Yes & Oct-19 & NASA Johnson Space Center & No \\
\hline 1 & U.S. & Yes & Sep-19 & Florida Power and Light / Nextera & No \\
\hline 1 & U.S. & Yes & Sep-19 & NASA - Glenn Research Center (1) & No \\
\hline 1 & U.S. & Yes & Sep-19 & SHINE Medical Technologies & No \\
\hline 3 & U.S. & Yes & Sep-19 & Baker Hughes - GE Company & No \\
\hline 1 & Non-U.S. & Yes & Sep-19 & Energy Safety Group LLC (Ukraine) & No \\
\hline 1 & Non-U.S. & Yes & Jul-19 & Panstwowa Agencja Atomistyki (PAA) & No \\
\hline 1 & Non-U.S. & Yes & Jun-19 & NT Engineering, LLC & No \\
\hline
\end{tabular}




\begin{tabular}{|c|c|c|c|c|c|}
\hline 1 & U.S. & Yes & Jun-19 & Southern Nuclear Company (SNC) & No \\
\hline 1 & U.S. & Yes & Jun-19 & PSEG & No \\
\hline 1 & U.S. & Yes & May-19 & USAF 45th Space Wing & No \\
\hline 1 & U.S. & Yes & May-19 & Tennessee Valley Authority (TVA) & No \\
\hline 1 & U.S. & Yes & May-19 & Pacific Gas and Electric Company & No \\
\hline 1 & U.S. & Yes & Apr-19 & DTE Energy - Fermi NPP & No \\
\hline 1 & Non-U.S. & Yes & Apr-19 & $\begin{array}{l}\text { University of Stuttgart (Germany) Institute of Nuclear Technology } \\
\text { Energy Systems (IKE) }\end{array}$ & No \\
\hline 1 & U.S. & Yes & Feb-19 & Wolf Creek Nuclear Operating Corporation (WCNOC) & No \\
\hline 1 & U.S. & Yes & Feb-19 & Electric Power Research Institute (EPRI) & No \\
\hline 4 & U.S. & Yes & Feb-19 & Palisades Nuclear & No \\
\hline 8 & U.S. & Yes & Jan-19 & Energy Research Inc. & No \\
\hline 1 & U.S. & Yes & Dec-18 & Creative Systems International & No \\
\hline 1 & Non-U.S. & Yes & Nov-18 & $\begin{array}{l}\text { State Scientific and Technical Center for Nuclear and Radiation } \\
\text { Safety }\end{array}$ & No \\
\hline 1 & Non-U.S. & Yes & Nov-18 & Ghana Atomic Energy Commission (GAEC) & No \\
\hline 1 & Non-U.S. & Yes & Nov-18 & Consejo de Seguridad Nuclear & No \\
\hline 1 & U.S. & Yes & Sep-18 & Naval Sea Systems Command (NAVSEA) & No \\
\hline 1 & U.S. & Yes & Sep-18 & TerraPower LLC & No \\
\hline 2 & U.S. & Yes & Jun-18 & Idaho State University - Mike Calley & No \\
\hline 1 & U.S. & Yes & Jun-18 & Callaway Energy Center & No \\
\hline 1 & U.S. & Yes & May-18 & Thomas Murray Acute Management Strategies, LLC & No \\
\hline 2 & Non-U.S. & Yes & May-18 & GPA Engineering Pty. Ltd & No \\
\hline 1 & U.S. & Yes & May-18 & Sandia National Laboratories - Risk \& Reliability Analysis Department & No \\
\hline 1 & U.S. & Yes & Apr-18 & Naval Postgraduate School (NPS) & No \\
\hline 2 & Non-U.S. & Yes & Apr-18 & National Tsing Hua University & No \\
\hline 1 & U.S. & Yes & Apr-18 & Comanche Peak Nuclear Power Plant & No \\
\hline 1 & U.S. & Yes & Apr-18 & Nebraska Public Power District & No \\
\hline 1 & U.S. & Yes & Mar-18 & MITRE Corporation & No \\
\hline 1 & U.S. & Yes & Jan-18 & TSI / NTT Data Services & No \\
\hline 1 & U.S. & Yes & Jan-18 & Anadarko Petroleum Corporation & No \\
\hline
\end{tabular}




\begin{tabular}{|c|c|c|c|c|c|}
\hline 1 & Non-U.S. & Yes & Dec-17 & Korean Institute for Nuclear Nonproliferation and Control (KINAC) & No \\
\hline 2 & U.S. & Yes & Nov-17 & Bureau of Safety and Environmental Enforcement (BSEE) & No \\
\hline 1 & U.S. & Yes & Oct-17 & NASA Glenn Research Center & No \\
\hline 1 & U.S. & Yes & Oct-17 & South Texas Nuclear Operating Company & No \\
\hline 1 & Non-U.S. & Yes & Oct-17 & FS-Micro Corporation & No \\
\hline 1 & U.S. & Yes & Sep-17 & Duke Energy & No \\
\hline 1 & U.S. & Yes & Sep-17 & Entergy Nuclear Operations, Inc. Pilgrim Nuclear Power Station & No \\
\hline 1 & U.S. & Yes & Sep-17 & Southern Nuclear Operating Company & No \\
\hline 1 & U.S. & Yes & Sep-17 & Entergy / Indian Point & No \\
\hline 1 & U.S. & Yes & Aug-17 & Arizona Public Service Company & No \\
\hline 1 & U.S. & Yes & Aug-17 & Xcel Energy & No \\
\hline 1 & U.S. & Yes & Aug-17 & Insitu, Inc. - SEIT Systems Safety \& Airworthiness & No \\
\hline 1 & U.S. & Yes & Jul-17 & Arkansas Nuclear One / Entergy & No \\
\hline 1 & U.S. & Yes & Jun-17 & Sandia National Laboratory - Systems Analysis and Research & No \\
\hline 1 & U.S. & Yes & Jun-17 & University of Utah- Civil Engineering & No \\
\hline 3 & U.S. & Yes & Jun-17 & Los Alamos National Laboratory - LANL & No \\
\hline 1 & U.S. & Yes & May-17 & Air Force Wright Patterson Air Force Base (WPAFB) & No \\
\hline 1 & U.S. & Yes & May-17 & Southwest Research Institute (SwRI) & No \\
\hline 1 & U.S. & Yes & Apr-17 & Science and Technology Corporation & No \\
\hline 1 & U.S. & Yes & Apr-17 & NASA-JSC Johnson Space Center & No \\
\hline 1 & U.S. & Yes & Apr-17 & Joint Warfare Analysis Center (JWAC) & No \\
\hline 2 & U.S. & Yes & Mar-17 & John Hopkins University/Applied Physics Laboratory & No \\
\hline 100 & NASA & No & Feb-17 & NASA headquarters - Dr. Homayoon Dezfuli e-mail hdezfuli@nasa.gov & Yes \\
\hline 1 & U.S. & Yes & Feb-17 & Ed Krantz Consulting & No \\
\hline 25 & \begin{tabular}{|l|} 
NRC \\
Limited \\
\end{tabular} & No & Dec-16 & NRC Limited (no models access) & No \\
\hline 1 & U.S. & Yes & Nov-16 & Defense Nuclear Facilities Safety Board (DNFSB) & No \\
\hline 2 & U.S. & Yes & Oct-16 & Columbia Helicopters & No \\
\hline 1 & U.S. & Yes & Oct-16 & SEM Consulting LLC & No \\
\hline 1 & U.S. & Yes & Oct-16 & GAR Consulting & No \\
\hline
\end{tabular}




\begin{tabular}{|c|c|c|c|c|c|}
\hline 2 & Non-U.S. & Yes & Oct-16 & $\begin{array}{l}\text { Mexican Regulatory Agency - Head of Risk Management Comision } \\
\text { Nacional de Seguridad Nuclear y Salvaguardias (CNSNS) }\end{array}$ & No \\
\hline 2 & Non-U.S. & Yes & Oct-16 & Global Assett Solutions Pty Ltd & No \\
\hline 1 & Non-U.S. & Yes & Sep-16 & European Commission Joint Research Centre (JRC) & No \\
\hline 1 & Non-U.S. & Yes & Sep-16 & AGH University & No \\
\hline 1 & U.S. & Yes & Sep-16 & Entergy Nuclear Operations, Inc. Fitzpatrick & No \\
\hline 1 & U.S. & Yes & Aug-16 & Applied Research Associates (ARA) & No \\
\hline 1 & Non-U.S. & Yes & Aug-16 & University of Sao Paulo & No \\
\hline 1 & U.S. & Yes & Jul-16 & $\begin{array}{l}\text { Sandia National Laboratories Weapons Security Engineering (SNL- } \\
\text { WSE) }\end{array}$ & No \\
\hline 1 & U.S. & Yes & Jul-16 & CMA Technologies & No \\
\hline 1 & U.S. & Yes & May-16 & A I Solutions & No \\
\hline 1 & U.S. & No & May-16 & Univesiti Teknologi Malaysia - UTM & No \\
\hline 1 & U.S. & Yes & Apr-16 & Applied Research Associates (ARA) & No \\
\hline 3 & U.S. & Yes & Apr-16 & Columbia Generating Station Energy Northwest & No \\
\hline 1 & U.S. & Yes & Apr-16 & Stanford Linear Accelerator Center (SLAC) & No \\
\hline 1 & \begin{tabular}{|l|} 
Special \\
NRC Cont.
\end{tabular} & No & Apr-16 & $\begin{array}{l}\text { IESS (Innovative Engineering \& Safety Solutions, LLC) Subcontractor } \\
\text { to ISL }\end{array}$ & No \\
\hline 3 & Non-U.S. & Yes & Mar-16 & INVAP SE, Argentina & No \\
\hline 1 & Non-U.S. & Yes & Mar-16 & Turkish Atomic Energy Authority (TAEK) & No \\
\hline 1 & U.S. & Yes & Feb-16 & Sandia Laboratory - Liao & No \\
\hline 1 & U.S. & Yes & Jan-16 & Westinghouse Electric Company & No \\
\hline 1 & U.S. & Yes & Dec-15 & Lockheed Martin & No \\
\hline 1 & U.S. & Yes & Oct-15 & Analytical Mechanics Associates (AMA) - NASA Ames support & No \\
\hline 1 & U.S. & Yes & Sep-15 & Entergy Nuclear Operations, Inc. River Bend & No \\
\hline 1 & U.S. & Yes & Sep-15 & JBD Consulting & No \\
\hline 1 & U.S. & Yes & Sep-15 & PEMY Consulting & No \\
\hline 2 & U.S. & Yes & Aug-15 & Sandia Nation Laboratory (SNL-SAD) & No \\
\hline 2 & U.S. & Yes & Jun-15 & University of Maryland & No \\
\hline 1 & U.S. & Yes & May-15 & NIST National Bureau of Standards Reactor (NBSR) & No \\
\hline 1 & U.S. & Yes & May-15 & Sandia National Laboratories - Wind Energy Technologies & No \\
\hline
\end{tabular}




\begin{tabular}{|c|c|c|c|c|c|}
\hline 1 & U.S. & Yes & May-15 & OCEANEERING SPACE SYSTEMS & No \\
\hline 1 & Non-U.S. & Yes & May-15 & CSIRO Computational Informatics & No \\
\hline 1 & U.S. & Yes & Apr-15 & Nuclear Safety Associates & No \\
\hline 1 & U.S. & Yes & Mar-15 & Florida Power \& Light (FPL) & No \\
\hline 1 & U.S. & Yes & Mar-15 & Global Engineering Services (GES) Lyondell Basell & No \\
\hline 3 & Non-U.S. & Yes & Mar-15 & Scientific and Technical Centre, Ukraine & No \\
\hline 2 & U.S. & Yes & Feb-15 & MIT & No \\
\hline 1 & U.S. & Yes & Feb-15 & American Electric Power (AEP) D.C. Cook & No \\
\hline 1 & U.S. & Yes & Dec-14 & Sandia National Laboratory - System Test and Hardware & No \\
\hline 1 & U.S. & Yes & Dec-14 & ASCA Inc. & No \\
\hline 1 & U.S. & Yes & Nov-14 & $\begin{array}{l}\text { Sandia National Laboratory Risk \& Reliability Analysis group (SNL- } \\
\text { RRA) }\end{array}$ & No \\
\hline 2 & U.S. & Yes & Nov-14 & Bechtel Power Corporation & No \\
\hline 1 & U.S. & Yes & Sep-14 & Rolls-Royce (PKMJ Technical Services Inc.) & No \\
\hline 1 & U.S. & Yes & Aug-14 & DOE's National Nuclear Security Administration (DOE/NNSA) & No \\
\hline 9 & Non-U.S. & Yes & Jul-14 & Korea Institute of Nuclear Safety (KINS) & No \\
\hline 1 & U.S. & Yes & Jul-14 & NASA Goddard Applied Engineering (NASA-GSFC-AETD) & No \\
\hline 1 & U.S. & Yes & May-14 & Los Alamos National Laboratory (LANL) & No \\
\hline 1 & U.S. & Yes & May-14 & NASA Langley Research Center & No \\
\hline 1 & U.S. & Yes & May-14 & US Air Force Kirtland Air Force Base & No \\
\hline 3 & U.S. & Yes & Apr-14 & Boeing - Colorado Springs & No \\
\hline 7 & U.S. & Yes & Apr-14 & Northrup Grumman & No \\
\hline 7 & U.S. & Yes & Apr-14 & ARES Corporation & No \\
\hline 5 & U.S. & Yes & Apr-14 & Raytheon Missile Systems & No \\
\hline 9 & U.S. & Yes & Apr-14 & Orbital Sciences Corporation & No \\
\hline 1 & U.S. & Yes & Feb-14 & Naval Surface Warfare Center Crane Division (NSWC Crane) & No \\
\hline 1 & U.S. & Yes & Jan-14 & Federal Aviation Administration (FAA) & No \\
\hline 15 & \begin{tabular}{|l|} 
Special \\
NRC Cont.
\end{tabular} & Yes & Dec-13 & ISL Inc. Rockville with SPAR access & No \\
\hline 1 & U.S. & Yes & Nov-13 & Jerricho Solutions Inc. & No \\
\hline 1 & Non-U.S. & Yes & Nov-13 & Federal Authority for Nuclear Regulation (FANR) & No \\
\hline
\end{tabular}




\begin{tabular}{|c|c|c|c|c|c|}
\hline 1 & U.S. & Yes & Oct-13 & Argonne National Laboratory & No \\
\hline 1 & U.S. & Yes & Oct-13 & ARES Technical Services Corp. & No \\
\hline 1 & U.S. & Yes & Aug-13 & Savannah River Nuclear Solutions, LLC & No \\
\hline 4 & U.S. & Yes & Aug-13 & Pacific Northwest National Laboratory & No \\
\hline 9 & Non-U.S. & Yes & Jul-13 & Korea Atomic Energy Research Institute & No \\
\hline 7 & Non-U.S. & Yes & Jul-13 & Korea Hydro \& Nuclear Power Co. & No \\
\hline 3 & Non-U.S. & Yes & Jun-13 & KEPCO Engineering and Construction & No \\
\hline 8 & U.S. & Yes & Jun-13 & PPL Susquehanna, LLC & No \\
\hline 4 & U.S. & Yes & Jun-13 & Brookhaven Science Associates, LLC & No \\
\hline 1 & U.S. & Yes & Mar-13 & Orbital Technologies Corporation (Orbitec) & No \\
\hline 4 & U.S. & Yes & Mar-13 & PSEG Nuclear, LLC & No \\
\hline 5 & U.S. & Yes & Mar-13 & Sierra Nevada Corporation & No \\
\hline 6 & U.S. & Yes & Nov-12 & South Carolina Electric \& Gas Co. & No \\
\hline 5 & Non-U.S. & Yes & Nov-12 & Rivne Nuclear Power Plant & No \\
\hline 6 & Non-U.S. & Yes & Nov-12 & Zaporozhye Nuclear Power Plant & No \\
\hline 5 & Non-U.S. & Yes & Sep-12 & Canadian Nuclear Safety Commission & No \\
\hline 3 & U.S. & Yes & Sep-12 & ISL Inc. New York Non-SPAR account & No \\
\hline 1 & U.S. & Yes & Jul-12 & U.S. Department of Transportation & No \\
\hline 4 & Non-U.S. & Yes & Jul-12 & Energorisk, Ltd. & No \\
\hline 3 & Non-U.S. & Yes & Jul-12 & Institute of Nuclear Energy Research & No \\
\hline 1 & U.S. & Yes & May-12 & Sandia National Laboratories & No \\
\hline 1 & U.S. & Yes & May-12 & $\begin{array}{l}\text { IESS (Innovative Engineering and Safety Solutions) Non-NRC Special } \\
\text { Account User }\end{array}$ & No \\
\hline 1 & U.S. & No & May-12 & PPG Industries, Inc. & No \\
\hline 1 & Non-U.S. & No & Apr-12 & Ferrocarril Metropolità de Barcelona, s.a. & No \\
\hline 1 & U.S. & No & Apr-12 & TIWALA Services & No \\
\hline 1 & U.S. & Yes & Apr-12 & L-3 Communications & No \\
\hline 2 & U.S. & No & Mar-12 & XE Corporation & No \\
\hline 1 & U.S. & No & Mar-12 & Aerospace Corporation & No \\
\hline 1 & U.S. & Yes & Mar-12 & Applied Research Associates, Inc. & No \\
\hline 1 & Non-U.S. & Yes & Mar-12 & Hendsa Technology Pty. Ltd. & No \\
\hline
\end{tabular}




\begin{tabular}{|l|l|l|l|l|c|}
\hline 1 & U.S. & Yes & Feb-12 & Dominion Resources Services (DRS) & No \\
\hline 1 & U.S. & Yes & Oct-11 & First Energy Nuclear Operating Company & No \\
\hline 1 & U.S. & Yes & Oct-11 & ERIN Engineering & No \\
\hline 1 & U.S. & Yes & Aug-11 & Entergy Services, Inc. & No \\
\hline 1 & U.S. & Yes & Aug-11 & Florida Power \& Light & No \\
\hline 1 & U.S. & Yes & Jul-11 & Naval Surface Warfare Center & No \\
\hline 1 & U.S. & Yes & Jul-11 & Pantex Site Office / Department of Energy & No \\
\hline 1 & U.S. & No & May-10 & Ciba Specialty Chemicals & No \\
\hline 1 & U.S. & No & Mar-10 & AREVA NP, Inc & No \\
\hline 1 & U.S. & No & Feb-10 & The Boeing Company - Saint Louis & No \\
\hline 1 & U.S. & No & Feb-10 & Florida Power \& Light & No \\
\hline 2 & U.S. & No & Jan-10 & Wyle Labs & \\
\hline
\end{tabular}


Table 2. Login accounts.

\begin{tabular}{|c|c|c|c|c|}
\hline Date of Last Login & $\begin{array}{l}\text { Login } \\
\text { Count }\end{array}$ & User & Email & Org \\
\hline 2019-Oct-21 07:14 PM & 750 & Knudsen, Jim & James.Knudsen@inl.gov & The INL SAPHIRE User's Group \\
\hline 2019-Oct-21 02:27 PM & 3 & Kolcum, Greg & Gregory.Kolcum@nrc.gov & Nuclear Regulatory Commission \\
\hline 2019-Oct-21 01:49 PM & 203 & Gonzalez, Michelle & michelle.gonzalez@nrc.gov & Nuclear Regulatory Commission \\
\hline 2019-Oct-21 12:03 PM & 44 & Sant, Robert & Robert.Sant@inl.gov & The INL SAPHIRE User's Group \\
\hline 2019-Oct-21 09:19 AM & 224 & Wood, Jeffery J. & Jeffery.Wood@nrc.gov & Nuclear Regulatory Commission \\
\hline 2019-Oct-21 07:31 AM & 3 & Haeg, Lucas & Lucas.Haeg@nrc.gov & Nuclear Regulatory Commission \\
\hline 2019-Oct-21 07:04 AM & 4 & Croon, Greg & Gregory.Croon@nrc.gov & Nuclear Regulatory Commission \\
\hline 2019-Oct-21 06:57 AM & 4 & Bousquet, Earl & Earl.Bousquet@nrc.gov & Nuclear Regulatory Commission \\
\hline 2019-Oct-21 04:56 AM & 1 & Felts, Russell & Russell.Felts@nrc.gov & Nuclear Regulatory Commission \\
\hline 2019-Oct-18 01:38 PM & 154 & Kozak, Laura & Laura.Kozak@nrc.gov & Nuclear Regulatory Commission \\
\hline 2019-Oct-18 10:44 AM & 16 & Tobin, Margaret & Margaret.Tobin@nrc.gov & Nuclear Regulatory Commission \\
\hline 2019-Oct-18 10:21 AM & 1191 & Buell, Robert & Robert.Buell@inl.gov & The INL SAPHIRE User's Group \\
\hline 2019-Oct-18 09:34 AM & 367 & Hunter, Chris & Christopher.Hunter@nrc.gov & Nuclear Regulatory Commission \\
\hline 2019-Oct-17 08:52 AM & 483 & Zeek, Doug & Douglas.Zeek@inl.gov & The INL SAPHIRE User's Group \\
\hline 2019-Oct-17 06:04 AM & 176 & Deese, Rick & rick.deese@nrc.gov & Nuclear Regulatory Commission \\
\hline 2019-Oct-16 09:46 AM & 4 & Dickson, Elijah & Elijah.Dickson@nrc.gov & Nuclear Regulatory Commission \\
\hline 2019-Oct-15 12:18 PM & 37 & Alferink, Steven & Steven.Alferink@nrc.gov & Nuclear Regulatory Commission \\
\hline 2019-Oct-14 10:49 AM & 15 & Youngblood, Bob & robert.youngblood@inl.gov & The INL SAPHIRE User's Group \\
\hline 2019-Oct-11 11:23 AM & 41 & Schwab, Alexander & Alexander.Schwab@nrc.gov & Nuclear Regulatory Commission \\
\hline 2019-Oct-10 11:55 AM & 221 & Freeman, Scott & Scott.Freeman@nrc.gov & Nuclear Regulatory Commission \\
\hline 2019-Oct-10 07:24 AM & 127 & Leech, Matthew & Matthew.Leech@nrc.gov & Nuclear Regulatory Commission \\
\hline 2019-Oct-08 09:13 AM & 131 & Tetter, Keith & Keith.Tetter@nrc.gov & Nuclear Regulatory Commission \\
\hline 2019-Oct-08 09:13 AM & 156 & Arner, Frank & Frank.Arner@nrc.gov & Nuclear Regulatory Commission \\
\hline 2019-Oct-07 01:19 PM & 98 & Hanna, John & John.Hanna@nrc.gov & Nuclear Regulatory Commission \\
\hline 2019-Oct-07 09:52 AM & 43 & Helton, Donald & Donald.Helton@nrc.gov & Nuclear Regulatory Commission \\
\hline 2019-Oct-06 06:45 PM & 22 & Rosebrook, Andy & Andrew.Rosebrook@nrc.gov & Nuclear Regulatory Commission \\
\hline
\end{tabular}




\begin{tabular}{|c|c|c|c|c|}
\hline 2019-Oct-04 10:19 AM & 27 & Sandal, Shane & Shane.Sandal@nrc.gov & Nuclear Regulatory Commission \\
\hline 2019-Oct-03 10:25 AM & 62 & Vasavada, Shilp & Shilp.Vasavada@nrc.gov & Nuclear Regulatory Commission \\
\hline 2019-Oct-03 08:52 AM & 1 & Schappaugh, Jeff & $\begin{array}{l}\text { jschappaugh@jensenhughes.co } \\
\text { m }\end{array}$ & $\begin{array}{l}\text { ERIN Engineering and Research, Inc. (Jensen } \\
\text { Hughes) }\end{array}$ \\
\hline 2019-Oct-02 02:11 PM & 4 & Shaw, Erik & eshaw@jensenhughes.com & $\begin{array}{l}\text { ERIN Engineering and Research, Inc. (Jensen } \\
\text { Hughes) }\end{array}$ \\
\hline 2019-Oct-02 08:30 AM & 26 & DeJesus, Jonathan & jonathan.dejesus@nrc.gov & Nuclear Regulatory Commission \\
\hline 2019-Oct-02 08:09 AM & 77 & Ma, Zhegang & Zhegang.Ma@inl.gov & The INL SAPHIRE User's Group \\
\hline 2019-Oct-02 06:14 AM & 3 & Facemire, John & jfacemire@jensenhughes.com & $\begin{array}{l}\text { ERIN Engineering and Research, Inc. (Jensen } \\
\text { Hughes) }\end{array}$ \\
\hline 2019-Oct-02 06:06 AM & 10 & Torres, Edgardo & Edgardo.Torres@nrc.gov & Nuclear Regulatory Commission \\
\hline 2019-Oct-01 03:43 PM & 2 & Money, Douglas & dmoney@jensenhughes.com & $\begin{array}{l}\text { ERIN Engineering and Research, Inc. (Jensen } \\
\text { Hughes) }\end{array}$ \\
\hline 2019-Oct-01 01:31 PM & 2 & Hufnal, Jared & jhufnal@jensenhughes.com & $\begin{array}{l}\text { ERIN Engineering and Research, Inc. (Jensen } \\
\text { Hughes) }\end{array}$ \\
\hline 2019-Sep-30 01:14 PM & 108 & $\mathrm{Ng}$, Ching & Ching.Ng@nrc.gov & Nuclear Regulatory Commission \\
\hline 2019-Sep-30 08:52 AM & 4 & Boyce, Jordan & Jordan.Boyce@inl.gov & The INL SAPHIRE User's Group \\
\hline 2019-Sep-27 06:24 AM & 80 & Kichline, Michelle & Michelle.Kichline@nrc.gov & Nuclear Regulatory Commission \\
\hline 2019-Sep-26 12:12 AM & 3 & Thabethe, Sibongiseni & SThabethe@nnr.co.za & South African National Nuclear Regulator (NNR) \\
\hline 2019-Sep-25 08:54 AM & 4 & Faris, Robert & farisrd@westinghouse.com & Westinghouse Columbia Fuel Fabrication Facility \\
\hline 2019-Sep-19 11:42 AM & 210 & Sancaktar, Selim & Selim.Sancaktar@nrc.gov & Nuclear Regulatory Commission \\
\hline 2019-Sep-19 11:23 AM & 26 & Zoulis, Antonios & Antonios.Zoulis@nrc.gov & Nuclear Regulatory Commission \\
\hline 2019-Sep-18 01:01 PM & 76 & Mitman, Jeff & Jeffrey.Mitman@nrc.gov & Nuclear Regulatory Commission \\
\hline 2019-Sep-18 06:41 AM & 8 & Gran, Zachary & Zachary.Gran@nrc.gov & Nuclear Regulatory Commission \\
\hline 2019-Sep-17 11:01 AM & 48 & Spore, Candace & Candace.Spore@nrc.gov & Nuclear Regulatory Commission \\
\hline 2019-Sep-17 08:25 AM & 21 & St. Peters, Courtney & Courtney.Stpeters@nrc.gov & Nuclear Regulatory Commission \\
\hline 2019-Sep-16 10:00 AM & 2 & Miller, Eric & Eric.Miller@nrc.gov & Nuclear Regulatory Commission \\
\hline 2019-Sep-16 07:13 AM & 77 & Cahill, Christopher & Christopher.Cahill@nrc.gov & Nuclear Regulatory Commission \\
\hline 2019-Sep-13 08:23 AM & 10 & Wagner, Brian & Brian.Wagner@nrc.gov & Nuclear Regulatory Commission \\
\hline 2019-Sep-10 08:28 AM & 39 & Dennis, Suzanne & Suzanne.Dennis@nrc.gov & Nuclear Regulatory Commission \\
\hline 2019-Sep-09 12:29 PM & 14 & Draxton, Mark & Mark.Draxton@nrc.gov & Nuclear Regulatory Commission \\
\hline
\end{tabular}




\begin{tabular}{|c|c|c|c|c|}
\hline 2019-Sep-09 09:46 AM & 16 & McKown, Lou & Louis.Mckown@nrc.gov & Nuclear Regulatory Commission \\
\hline 2019-Sep-06 01:23 PM & 26 & Matos, Craig & CMatos@jensenhughes.com & $\begin{array}{l}\text { ERIN Engineering and Research, Inc. (Jensen } \\
\text { Hughes) }\end{array}$ \\
\hline 2019-Sep-06 09:55 AM & 5 & Kuritzky, Alan & Alan.Kuritzky@nrc.gov & Nuclear Regulatory Commission \\
\hline 2019-Sep-05 11:36 AM & 48 & Calley, Mike & Michael.Calley@inl.gov & The INL SAPHIRE User's Group \\
\hline 2019-Sep-05 05:22 AM & 2 & Ellegood, John & John.Ellegood@nrc.gov & Nuclear Regulatory Commission \\
\hline 2019-Sep-04 08:50 AM & 9 & Campbell, Brant & Brant.Campbell@inl.gov & The INL SAPHIRE User's Group \\
\hline 2019-Sep-03 03:23 PM & 50 & $\begin{array}{l}\text { Wang, Zeechung } \\
\text { (Gary) }\end{array}$ & zeechung.wang@nrc.gov & Nuclear Regulatory Commission \\
\hline 2019-Sep-03 02:33 PM & 10 & Wu, De & De.Wu@nrc.gov & Nuclear Regulatory Commission \\
\hline 2019-Sep-03 02:18 PM & 4 & Parent, Jason & Jason.Parent@nrc.gov & Nuclear Regulatory Commission \\
\hline \begin{tabular}{|l|} 
2019-Sep-03 12:35 PM \\
\end{tabular} & 1 & Carneal, Jason & Jason.Carneal@nrc.gov & Nuclear Regulatory Commission \\
\hline 2019-Sep-03 10:58 AM & 1 & Sigmon, Rebecca & Rebecca.Sigmon@nrc.gov & Nuclear Regulatory Commission \\
\hline 2019-Sep-03 10:21 AM & 1 & Hernandez, Raul & Raul.Hernandez@nrc.gov & Nuclear Regulatory Commission \\
\hline 2019-Sep-03 09:26 AM & 4 & Kodali, Hari & Hari.Kodali@nrc.gov & Nuclear Regulatory Commission \\
\hline 2019-Aug-30 05:13 AM & 5 & Marksberry, Don & Don.Marksberry@nrc.gov & Nuclear Regulatory Commission \\
\hline 2019-Aug-29 08:37 AM & 3 & Finney, Patrick & Patrick.Finney@nrc.gov & Nuclear Regulatory Commission \\
\hline 2019-Aug-28 09:36 AM & 6 & Bywater, Russell & Russell.Bywater@nrc.gov & Nuclear Regulatory Commission \\
\hline 2019-Aug-28 09:02 AM & 4 & Fuller, Justin & Justin.Fuller@nrc.gov & Nuclear Regulatory Commission \\
\hline 2019-Aug-28 08:25 AM & 4 & Lawrence, Svetlana & Ilawrence@enercon.com & Enercon \\
\hline 2019-Aug-27 12:21 PM & 164 & Circle, Jeff & Jeff.Circle@nrc.gov & Nuclear Regulatory Commission \\
\hline 2019-Aug-27 09:05 AM & 4 & Neuhausen, Alissa & Alissa.Neuhausen@nrc.gov & Nuclear Regulatory Commission \\
\hline 2019-Aug-27 07:37 AM & 233 & MacDonald, George & George.MacDonald@nrc.gov & Nuclear Regulatory Commission \\
\hline 2019-Aug-23 09:08 AM & 1 & Toth, Matthew & Matthew.Toth@nrc.gov & Nuclear Regulatory Commission \\
\hline 2019-Aug-23 08:59 AM & 1 & Deschaine, Wesley & Wesley.Deschaine@nrc.gov & Nuclear Regulatory Commission \\
\hline 2019-Aug-22 08:20 PM & 12 & Goel, Vijay & Vijay.Goel@nrc.gov & Nuclear Regulatory Commission \\
\hline 2019-Aug-22 01:20 PM & 2 & Smith, Cassandra & Cassandra.Smith@nrc.gov & Nuclear Regulatory Commission \\
\hline 2019-Aug-22 08:46 AM & 18 & Fanelli, Theodore & Theodore.Fanelli@nrc.gov & Nuclear Regulatory Commission \\
\hline \begin{tabular}{|l|} 
2019-Aug-22 08:07 AM \\
\end{tabular} & 10 & Childs, Natasha & Natasha.Childs@nrc.gov & Nuclear Regulatory Commission \\
\hline 2019-Aug-21 07:34 PM & 26 & Ueda, Haruaki & haruaki_ueda@nsr.go.jp & Nuclear Regulation Authority (NRA, Japan) \\
\hline
\end{tabular}




\begin{tabular}{|c|c|c|c|c|}
\hline 2019-Aug-21 12:44 PM & 58 & Fairfax, Steve & fairfax@mtechnology.net & MTechnology, Inc. \\
\hline 2019-Aug-21 08:26 AM & 2 & Stephen, Thomas & Thomas.Stephen@nrc.gov & Nuclear Regulatory Commission \\
\hline 2019-Aug-21 05:31 AM & 11 & Meier, Peter & Peter.Meier@nrc.gov & Nuclear Regulatory Commission \\
\hline 2019-Aug-20 03:10 PM & 2 & Paulos, Todd & Todd.Paulos@jpl.nasa.gov & NASA - Jet Propulsion Lab \\
\hline 2019-Aug-20 02:15 PM & 3 & Railsback, Jan & jan@metonanalysis.com & Meton Analysis, Inc. \\
\hline 2019-Aug-20 11:24 AM & 32 & Nakanishi, Tony & Tony.Nakanishi@nrc.gov & Nuclear Regulatory Commission \\
\hline 2019-Aug-16 12:47 PM & 111 & Loveless, David & David.Loveless@nrc.gov & Nuclear Regulatory Commission \\
\hline 2019-Aug-15 11:27 AM & 21 & Riggs, Eric & Eric.Riggs@nrc.gov & Nuclear Regulatory Commission \\
\hline 2019-Aug-15 09:39 AM & 2 & Olvera, John & john.olvera@shinemed.com & SHINE Medical Technologies \\
\hline 2019-Aug-14 02:02 PM & 189 & Wood, Ted & Ted.Wood@inl.gov & The INL SAPHIRE User's Group \\
\hline 2019-Aug-14 09:52 AM & 1 & Fernandez, Juan & Juan.Fernandez@nrc.gov & Nuclear Regulatory Commission \\
\hline 2019-Aug-14 09:09 AM & 1 & Henry, Corey & Corey.Henry@nrc.gov & Nuclear Regulatory Commission \\
\hline 2019-Aug-13 02:38 PM & 14 & Marden, James & jmarden@arescorporation.com & Boeing - Huntsville \\
\hline 2019-Aug-12 11:18 AM & 12 & Werkheiser, David & David.Werkheiser@nrc.gov & Nuclear Regulatory Commission \\
\hline 2019-Aug-12 10:52 AM & 24 & Henry, Dan & Daniel.Henry@inl.gov & The INL SAPHIRE User's Group \\
\hline 2019-Aug-08 11:43 AM & 6 & Averett, Mark & mark.averett@fpl.com & Florida Power and Light / Nextera \\
\hline 2019-Aug-08 11:39 AM & 45 & Doyle, Jeremiah & jdoyle@nuscalepower.com & NuScale Power, Inc. \\
\hline 2019-Aug-08 11:23 AM & 2 & Coffman, Zach & zachary.coffman@nrc.gov & Nuclear Regulatory Commission \\
\hline 2019-Aug-08 04:57 AM & 7 & \begin{tabular}{|l|} 
Humberstone, \\
Matthew \\
\end{tabular} & Matthew.Humberstone@nrc.gov & Nuclear Regulatory Commission \\
\hline 2019-Aug-07 04:55 PM & 6 & Sunde, Nik & nik.sunde@orbitalatk.com & Boeing - Huntsville \\
\hline 2019-Aug-07 12:57 PM & 10 & Gonzalez, Felix & Felix.Gonzalez@nrc.gov & Nuclear Regulatory Commission \\
\hline 2019-Aug-07 11:41 AM & 52 & Yeilding, Dale & Dale.Yeilding@nrc.gov & Nuclear Regulatory Commission \\
\hline 2019-Aug-07 10:15 AM & 17 & Speer, Chris & Chris.Speer@nrc.gov & Nuclear Regulatory Commission \\
\hline 2019-Aug-07 09:33 AM & 2 & Haley, Brandon & bhaley@nuscalepower.com & NuScale Power, Inc. \\
\hline 2019-Aug-07 08:23 AM & 27 & Driver, Adrienne & Adrienne.Driver@nrc.gov & Nuclear Regulatory Commission \\
\hline 2019-Aug-07 07:48 AM & 14 & Kumana, Rayo & Rayomand.Kumana@nrc.gov & Nuclear Regulatory Commission \\
\hline 2019-Aug-07 07:04 AM & 22 & Gilbertson, Anders & Anders.Gilbertson@nrc.gov & Nuclear Regulatory Commission \\
\hline 2019-Aug-07 05:45 AM & 3 & Kim, Yoonik & Yoonik.Kim@fmglobal.com & FM Global \\
\hline
\end{tabular}




\begin{tabular}{|l|c|l|l|l|}
\hline 2019-Aug-07 05:14 AM & 2 & Choate, Eric & eric.d.choate@nasa.gov & NASA - Glenn Research Center (1) \\
\hline 2019-Aug-07 12:35 AM & 2 & Polianskiy, Mikhail & polianskiy@e-s-group.com.ua & Energy Safety Group LLC (Ukraine) \\
\hline 2019-Aug-06 08:20 PM & 8 & Wolfgang, Robert & rwolfgang@jensenhughes.com & $\begin{array}{l}\text { ERIN Engineering and Research, Inc. (Jensen } \\
\text { Hughes) }\end{array}$ \\
\hline 2019-Jul-29 09:59 AM & 2 & Hardage, David & David.Hardage@nrc.gov & Nuclear Regulatory Commission \\
\hline 2019-Jul-26 08:39 AM & 1 & Hollcraft, Zachary & Zachary.Hollcraft@nrc.gov & Nuclear Regulatory Commission \\
\hline 2019-Jul-25 08:23 AM & 7 & Scott, Christian & Christian.Scott@nrc.gov & Nuclear Regulatory Commission \\
\hline 2019-Jul-23 11:30 AM & 4 & Hunt, Christopher & Christopher.Hunt@nrc.gov & Nuclear Regulatory Commission \\
\hline 2019-Jul-22 10:06 AM & 45 & Biro, Mihaela & Mihaela.Biro@nrc.gov & Nuclear Regulatory Commission \\
\hline 2019-Jul-18 10:19 AM & 140 & Kvarfordt, Kellie & kellie.kvarfordt@inl.gov & The INL SAPHIRE User's Group \\
\hline 2019-Jul-15 05:19 AM & 2 & Vettori, Robert & Robert.Vettori@nrc.gov & Nuclear Regulatory Commission \\
\hline 2019-Jul-14 01:31 PM & 14 & Leschek, Walter & Walter.Leschek@nrc.gov & Nuclear Regulatory Commission \\
\hline 2019-Jul-11 09:45 AM & 13 & Schussler, Jason & Jason.Schussler@nrc.gov & Nuclear Regulatory Commission \\
\hline 2019-Jul-10 07:10 AM & 12 & Nelson, Alexis & Alexis.Nelson@nrc.gov & Nuclear Regulatory Commission \\
\hline 2019-Jul-09 02:52 PM & 1 & Rogers, James & jim.rogers@nasa.gov & MARS2020-RIUWG \\
\hline 2019-Jul-03 09:37 AM & 27 & Vedros, Kurt & kurt.vedros@inl.gov & The INL SAPHIRE User's Group \\
\hline 2019-Jun-27 11:55 AM & 9 & Hilsmeier, Todd & Todd.Hilsmeier@nrc.gov & Nuclear Regulatory Commission \\
\hline 2019-Jun-20 03:02 PM & 36 & Montecalvo, Michael & Michael.Montecalvo@nrc.gov & Nuclear Regulatory Commission \\
\hline 2019-Jun-19 09:06 AM & 10 & Morrissey, Thomas & Thomas.Morrissey@nrc.gov & Nuclear Regulatory Commission \\
\hline
\end{tabular}

